\title{
Ethics of Sustainable Development from the View of A. Badiou's Critique of Contemporary Ethics
}

\section{Etyka zrównoważonego rozwoju z perspektywy A. Badiou krytyki etyki współczesnej}

\author{
Andrzej Papuziński \\ Uniwersytet Kazimierza Wielkiego, Wydziat Humanistyczny, \\ Instytut Nauk Politycznych, ul. ks. J. Poniatowskiego 12, 85-671 Bydgoszcz, Poland \\ E-mail: papuzin@ukw.edu.pl
}

\begin{abstract}
The main problem of that article is effectiveness / ineffectiveness of an axiological system of the sustainable development as the base of a program of activities taken in individual and social-political scale. The problem was presented from the view of Alain Badiou's ethics, which is a trial of overcoming weaknesses of the contemporary ethics of the mainstream, especially very low effectiveness of the ethics in the sphere of social practice. For developing the title problem there was applied the critique of contemporary ethics as the ethics of consensus, conducted by Badiou. Established research prospect has a limited application. It allows exclusively and only for drawing a conclusions in the matter of possible usability of the ethics of sustainable development in the activities leading to the change of dominant stereotypes of thinking and standards of conduct nowadays. From the point of view of Badiou's ethics this is the first, but necessary step on the way to answer a following question - does the ethic of sustainable development have actual causative power and is it effective in initiating and performing social changes?
\end{abstract}

Key words: ethics, practical effectiveness of ethics, sustainable development, Badiou

\section{Streszczenie}

Głównym problemem artykułu jest skuteczności/nieskuteczności systemu aksjologicznego zrównoważonego rozwoju jako podstawy programu działań podejmowanych w skali społeczno-politycznej oraz indywidualnej. Zagadnienie zostało przedstawione z perspektywy etyki Alaina Badiou, która jest próbą przezwyciężenia słabości etyki współczesnej głównego nurtu, zwłaszcza bardzo niskiej skuteczności tej etyki w sferze praktyki społecznej. Do rozwinięcia tytułowego problemu zastosowano przeprowadzoną przez Badiou krytykę etyki współczesnej jako etyki konsensu. Przyjęta perspektywa badawcza ma ograniczone zastosowanie. Pozwala tylko i wyłącznie na wysnucie wniosków w kwestii ewentualnej przydatności etyki zrównoważonego rozwoju w działaniach prowadzących do zmiany współcześnie dominujących stereotypów myślenia i standardów postępowania. Z punktu widzenia etyki Badiou jest to pierwszy, ale konieczny krok na drodze do udzielenia odpowiedzi na pytanie, czy etyka zrównoważonego rozwoju dysponuje rzeczywistą mocą sprawczą i jest skuteczna w inicjowaniu i przeprowadzaniu zmian społecznych?

Słowa kluczowe: etyka, praktyczna skuteczność etyki, zrównoważony rozwój, Badiou

\section{Introduction}

Ethical stances are the systems of norms and values. They are worked out in order to shape an individual and social awareness - and what follows the above attitudes and manners in the way compatible with accepted idea of proper relations between a man and elements of anyhow differently understood the community of life of the man. For that reason the ethics is the field of study of practical philosophy. The vital task of ethics is initiating activities pursuing an aim of implementing that what 
according to the idea should be accepted in it. Referring to the Rawls characteristics of the idea it can be said that the main role of ethics consists in striving for realization of the general conviction about possibilities (or natural necessities, with a view to the theory of natural entitlements) of the life of man, what manifests itself in the form of an opinion on the subject of proper direction and correct purpose of the human life (Rawls, 2001). One of the values applied for assessment of ethical stances is the causative effectiveness in the execution of this task. The purpose of the article is the assessment of the ethics of sustainable development from the point of view of the above criterion. The assessment will be carried out from the prospect of the ethical outlook of Alain Badiou - and more precisely - his stance in the matter of contemporary ethics. The foregoing apposition has the vital meaning for further analyzes. The above addition has crucial meaning for further analyses. It means that the research problem taken up in this article is the possibility of classifying the sustainable development ethics to the collection of ethical theories which may, if need be, dispose of sufficient potential in inspiring individuals and communities to activities aimed at social change. An answer for a question, if the sustainable development ethics actually disposes of such a potential, does not enter into the range of the research problem taken up on these pages. The question may be only answered after taking into consideration successive aspects of ethical stance of Badiou, in the first place his own ethical theory, so called an ethics of truth. But that is already another problem. It can only be reasonably put until positive settling of the problem considered in the text.

The choice of Badiou's theory for the needs of analyses researched below was motivated by the specificity of the stance. Causative effectiveness of the ethics is one of the main points of the ethical investigations of the French philosopher. The question about conditions which will ensure the ethics the possibility of causative effectiveness, occupy him to the extent, which in this respect favours him strongly amongst the contemporary ethicists.

\section{Badiou's Critique of Contemporary Ethics}

In his critique of contemporary ethics which he calls as consensual ethics, Badiou descents from an obvious proposition on the subject of historical distinction of the subject, purposes and tasks of ethical theories from the different periods of philosophy. Passing medieval period over in silence he points at the different nature of ancient, modern and contemporary ethics. The ancient ethics heads to subordinating life practice to the universal representation of Good. As a teacher of the art of good life it is the synonym of wisdom. It focuses on implementation of a man to rational managing his own conduct on the basis of ability of distinguishing matters dependent on him and independent on him. The modern ethics gravitates between practical activities of the subject - comprehended as an individual as well as a community - in searching for the rule of pronouncing judgments on the subject of their moral value, assessment in categories of good and evil. In the modern depiction the ethics is the synonym of practical, common sense. It concentrates on relations between intentions and actions of the subject and universal Law. The contemporary ethics of the mainstream differs strongly from both the previous types of reflections over morality. It is difficult to conclude it from among either of previous modes of ethical investigations. It is in much too more measure the result of the twilight of ideology in the middle of $20^{\text {th }}$ century than an heir of ethical heritage after the previous centuries (Badiou, 2001). The French philosopher directs many objections at the address of contemporary ethics of the mainstream. First of all he blames it for the acceptance of evasions of necessity and impoverishing emancipatory, militant, value of rules. The original $\sin$ of the contemporary ethical reflection is - in his opinion - the loss of idea of Good. Before the eyes of generations living today, a great and coherent idea of Good was changed on many unimportant things, the separate rules of commenting on isolated situations. Badiou highlights the disintegration of ethical reflection into questionable as regards their theoretical and practical quality the ethics of various spheres of human activity. Current outburst of interest in ethics after a long period of stagnation is related to difficulties which a man is faced with in situation devoid of suggestion from great narration in meeting a need of commenting on different matters. The present-day ethics is proverbial straw which confounded people catch, drowning from the lack of knowledge, orientation in the world, which lost clear ideological poles. It replaces the old ideological divisions springing from the general impression brought about by visions of atrocities and becomes in that way the consensual ethics. It allows a man for regaining orientation in reality on the basis of objection to various disturbances of Evil, which in way statistically significant makes up to the shared human experience (Badiou, 2001).

Concretizing his objections in the matter of acceptance by the consensual ethics of the evasions of necessity Badiou moves accent on the critique of political engaging of ethical reflection. According to him ethical objectivity is de facto an economic objectivity. This degrading consensus around the existing state of affairs is controlled by logic of capital (Badiou, 2001). That ethics whatsoever does not deserve its name, it is - as Badiou proposes to name it in Greek - eunicosa, i.e. a happy nihilism. It is the nihilism because it does not even have the smallest relation to any better vision of the future and 
shuts out ruthless domination of the status quo over individual and social dimension of life. At the same time it is a certain vision of happiness, because what for the West is here and now, the West presents in categories of exemplar in the scale of globe. Encourages popularizing western order, looking through rose-colored spectacles on the chain of objective economic needs which are characteristic for the West that is known for their legal discourse and cold reserve toward social matters. That ethics is an expression of conservative propaganda and gloomy anxiety for catastrophe (Badiou, 2001). Emphasizing the political aspects of contemporary ethical reflection Badiou does not however leave the theoretical ground of ethics. Because what he does is in fact that he considers the whole matter in the context of Good and Evil.

Answering the question dealing with a reason for transformation of ethics into the eunicose he underscores the role which in this process was played by separation of ethics from the idea of Good. The French philosopher knows perfectly well that the idea of Good may make a stimulus for inflicting evil and understands well why contemporary ethics of the mainstream resigned, under the influence of liberalism, from the category of the common good, but takes a firm stand which in ethics without the idea of Good does not see theory needed to practice. He underscores that the ethics built on the foundation of recognized a priori Evil is and must be ineffective because it is not able to show appreciation of any such social involvement which could undermine the roots from which this Evil grows and is restored to life. The ethics separated from the idea of Good leads to thinking which cannot break free from the vicious circle of affirmation of reality reproducing Evil against which it appears (Badiou, 2001).

The critique of mainstream contemporary ethics (consensual) performed by Badiou leads consistently to the total negation of its value. The philosopher calls for rejection of the ethics as the ethics constructed on ideological plan of conservatism in the wide, colloquial sense of the word, additionally abstract and characterized by statistical generality. The consensual ethics not only defends status quo but makes completely impossible thinking about specificity of situation, to which it relates rules and standards postulated by it.

\section{The Operationalism of Research Problem}

Referring to the remarks presented at the beginning of the article the sustainable development ethics will be defined as such an ethical standpoint in which the central position is taken by the political idea of sustainable development. According to the designation it can be comprehended in the descriptive and conceptual way. Considering a weak connection of the conceptual ethics of sustainable development with the practice, the subject of investigation will be limited to its descriptive version. In such sense by the sustainable development ethics should be understood the main values and the leading norms of programs, strategies and policies of sustainable development.

The trial of formulating an assessment of causative effectiveness of the sustainable development ethics on the basis of critique to which it was subjected by Badiou leads to asking the following questions:

1. Does the ethics of sustainable development accepts evasions of necessity? A positive answer is identical with joining the sustainable development ethics to the collection of conservative ethical theories, which are supervised by status quo logic but negative answer allows seeing in it the theory which can inspire for doing away with current stereotypes of grasping reality and customary standards of conduct.

2. Was the ethics of sustainable development built on the foundation of recognized a priori Evil? According to Badiou's standpoint the affirmative answer discredits the ethics of sustainable development as the ethics capable of effective change of reality but the negative answer lines it up with such ethical theories which can have a potential indispensable for fighting against the Evil.

3. Does the ethics of sustainable development have any vision of Good? This is the most important question. According to the standpoint of Badiou, without directing on Good the ethics of sustainable development will be totally defenseless in the face of prevailing form of cultural objectiveness and completely unable to take up fight against the Evil. Only referring to the vision of Good gives the ethics some chance. With a view to possible answers to questions concerning conformity or inconsistency of the ethics of sustainable development with contemporary ethics in the appointed above ranges the asymmetrical character of responses for yes and no should be underscored. The positive answer is a strong statement: it excludes the ethics of sustainable development from the amount of ethical theories having any potential of inspiring the social changes. The negative answer is a weak proposition: it only allows for the possibility of having such a potential by the ethics of sustainable development. What decides about that, if the ethics really has the potential or not is conformity with requirements which Badiou formulated at the address of his own project of ethics - the ethics of truth. The research problem raised in that article does not however require rising of this problem.

The answer for the questions raised above requires particularization of the subject of investigations. On this stage of research one cannot continue posing a question about the ethics of sustainable development as such without argument becoming entangled in the 
network of contradictions and nonsense. The basic difficulty comes from the fact that in actual fact there is not at all one ethics of sustainable development. Many mutually interchanging factors influence that. From the point of view of theory important are observations by Georg W.F. Hegel on the subject of objectivity of ideas. As the German philosopher reasons it is the unavoidable effect of entering of the idea into social circulation. In confrontation with experiences of other people, convictions and abilities it falls in the merry-go-round of dynamic process of interpretations and reinterpretations. As an addition come changes in social and political context of functioning of the idea. The idea formulated by Brundtland Commission in the period of cold war (1987) gained international recognition on the $1^{\text {st }}$ Earth Summit in Rio de Janeiro merely in six months after the collapse of the Union of Soviet Socialist Republics in the atmosphere of excitement brought about in the West by the fall of the empire of evil (1992) and already ten years later, on the $2^{\text {nd }}$ Earth Summit in Johannesburg had to turn up in the neoliberal world of globalized economy, infected by international terrorism (2002). The third matter concerns attempts of using the idea of sustainable development in political struggle for wealth, power and influence. In the atmosphere - as Michael Sandel calls it - market triumphalism, expansion of markets and market values on spheres of life where there should not be place for them (Sandel, 2012), the idea of sustainable development with no difficulty was appeased from its potentially antisystemic ethical shell. Referring to, implemented by Michael Walzer, distinction of ethics for thin and thick ethics, the ethics full of substance and not full of substance (Walzer, 1994) in discussed case it can be said that the distinctions appear on the stage of transformation from minimalist interpretation, as a matter o fact, the idea of sustainable development to (favoring direct action to achieve all the goals and rejecting compromise ) maximalist interpretation of the idea, recorded in programmes, strategies and policies of sustainable development, executed on the basis of subjective convictions of authors and represented by them economic and political interests and in relation to the new historical situation.

To sum up it can be said that in the course of years which have passed since conceptualization of the idea of sustainable development it has been repeatedly modified ${ }^{1}$ on various ways, as a result of that there are contemporarily close to each many different, now and then very different, even completely contradictory ethics of sustainable development. In that situation one needs to take

\footnotetext{
${ }^{1}$ Artur Pawłowski in a book from 2008, basing only on selected Polish and English scientific literature and UN, EU and Polish documents in the range of politics and the law of sustainable development, distinguished 50 various definitions of sustainable development (Pawłowski, 2001; c.f. also Redclift, 2009; Brand, 1997).
}

nominalistic positions, in other words, choose as a subject of research the concrete ethics of sustainable development, reconstructed on the basis of defined programme, strategy or policy of sustainable development ${ }^{2}$. From among them one deserves a special attention i.e. the ethics of sustainable development from the Brundtland Report, as the report of World Commission for Environment and Development entitled Our Common Future from the year 1987 was colloquially used to be determined. Firstly, considering its historical meaning, i.e. therefore that it is a crucial breakthrough document in the history of policy of sustainable development. Secondly because in it, as on rare occasions, the sustainable development was presented in the form of theory, in other words - again referring to the distinctions applied by John Rawls - the concept enriched with a description of the role of its own rules in defining that what demonstrates the idea lying at the foundation of the concept.

\section{Causative effectiveness of the ethics of sustainable development in the light of Badiou's standpoint}

Coming back to the questions. It seems that positive answer should be given for the first question. The Brundtland Report accepts straightforwardly and unavoidably the evasions of necessity. The document is an element of achievements of institutional UN system, the universal international organization, which after the Second World War was appointed to be on guard of a postwar status quo. Such evasions of necessity were thus first of all the objectives of United Nations Organization. In the conditions of cold war UN had to take into consideration the conditions, on which peace and international safety, development of co-operation between countries depended on and providing for obeying human rights (UN, 1945). The ethics of sustainable development was founded on the principles saying about not taking position in the issues of bases of system of competing with one another social-economic systems and the need for searching a common denominator on the space of technological aspects of touched issues.

On the other hand one cannot pass over in silence the trial of coming out of this political deadlock. The effort of the President of Commission Gro Harlem Brundtland should be underscored which was aimed at making Commission to the maximum independent of particularistic interests of individual groups of countries. As opposed to typical UN institutions the participants of the Brundtland Commission were

\footnotetext{
${ }^{2}$ The necessity of applying nominalistic prospect of the analysis of philosophy - including ethics - of sustainable development I have proved widely in another article (Papuziński, 2017).
} 
persons who were not the delegates of countries and governments but people representing their nations. In this symbolic way there was indicated a will to prepare new, universal paradigm of development, under which all interested parties could sign, be it on the capitalist West as well as on the socialist East, on the rich North as well as and on the poor South. The stress laid in the discussed report on spreading the technical progress, its bad and good effects, let us a conjecture that on the work of the Brundtland Commission impact was placed by the popular in that times theory of convergence. According to the theory of convergence technology is directed by its own, separate logic of development which brings in industrial societies on the common road to such a social-economic development where the societies come closer to each other in many respects especially in the manner of political organization, cultural forms and attitudes taken by people.

The ultimate answer for the first question must allow for the fact of taking up by the Brundtland Commission a trial of going outside the then socialeconomical realties. The theory of sustainable development worked out by it was a new developmental paradigm, in which the logic of technology dissolved both the logic of capitalism as well as the logic of centrally planned economy. In respect of the above it must be said ultimately that the ethics of sustainable development does not accept these evasions of necessity on which Badiou puts the main stress in his works.

Similarly to the case of the first question at the beginning one can have the impression that for the second question one should answer positively. Such an answer is brought by immanent interpretation of the text of the Brundtland Report carried out in separation from the new ethical standpoints, elaborated in those years under pressure from global issues to which this document was devoted. From the point of view of the structure of text of the Brundtland Report and adopted in it the train of thought the ethics of sustainable development is constructed on the foundation of recognized a priori Evil. We may say that in principle of many forms of Evil. The first part of the Brundtland Report was devoted to common worries and starts with the chapter entitled Successes and Failures. Already the first sentences of the chapter are a trial of naming Evil which the sustainable development is to stand up to. The Evil is first of all indifference of countries and societies on the effects of their own caring for surviving and prosperity on others. The evil is thus undue consumption i.e. consumption of the resources of earth in such a fast motion that not much will be left for the future generations. But evil is also too little consumption being fated to living in prospect of other kinds of concrete evil: famine, extreme poverty, illnesses and premature death. Evil is undue demand for rare resources and environmental pollution being the result of rising level of life of relatively rich people. But the evil is also destroying immediate surroundings by the poor and hungry that fights for survival. The Report paints a shocking picture of poverty in the world, characterizes many kinds of hazards, which economic growth entails, and also warns against the specter of global economic crisis (WCED, 1987).

On the other hand the Report may be regarded as a document subordinated to the logic of heuristics of fear. In the period of coming into being of the Brundtland Report the heuristics of fear understood as an ability of finding new facts and relations between the facts in result of anxieties inspired in a human being by the forecasts concerning the future - is the method widely applied by intellectualists interested in the future of mankind. As Hans Jonas maintains - a philosopher who in a book from 1979 made the heuristics of fear the main tool of disseminating the rules of ethics for the technical civilization - one should distinguish science about the rules of morality from the science about applying the rules. Acknowledging predominance to the question about moral rules he pays attention to the causative effectiveness of perceiving evil by a human being. He considers that experience of evil imposes itself on a man, is more convincing and less receptive to differences of opinions in comparison with the experience of good. Persuasive potential of the heuristics of fear is based on the conviction that a man makes sure about the good only through experiencing its contradiction (Jonas, 1979). Roberto Franzini Tibaldeo lists reasons which according to Jonas decide about the attractiveness of the heuristics of fear as a tool for popularizing desirable values and ideals in the social awareness. Among them the most important part plays the power of fear to consolidate all the dimensions of human existence as for example individual and collective, rational and emotional, theoretical and practical and its ability to stimulate imagination (Tibaldeo, 2015). So the heuristics of fear has nothing to do with the construction of ethical theory because it is the method of presentation of issues brought up in it.

To sum up the answer to the second question should be as follows. The ethics of sustainable development was not constructed on the foundation of recognized a priori Evil. Its actual foundation is the definite vision of Good.

Passing to the third and all the same the last question the answer should not be searched far, because it was already presented in conclusion concerning the previous affair. One can only repeat that the ethics of sustainable development from the Brundtland Report follows a certain vision of Good. Therefore what is that ethical good?

In conceptual respect the most important meaning for the ethics of sustainable development have initial remarks entitled From One Earth to One World, from which begins a long text of the discussed report. In 
that part were lain the foundations for global ethics, formulated on such a level which concerns all people, the present as well as the future generations. And also in this place, in the fragment entitled Sustainable Development were defined essential goods for which the sustainable development should serve. These goods are the moral rights of universal, intra - and intergenerational character. They include human rights to meet basic needs, preserving vital functions of ecosystems crucial from the point of view of the quality of human existence, fair access of individuals and communities to global reserves and also to extend for all people the possibilities of meeting aspirations for the better life (WCED, 1987). Listed goods were not put in order enough, in the document, to be able to speak, on this basis, about the system of basic ethical goods of sustainable development. Working out of that system does not agree with the fast transferring of accent from the essential moral goods of sustainable development into instrumental in relation to them the rule of global justice. However taking into account the role played by correct aspiration for better life in the formula of the rule of justice, that right for a better life should be recognized as a key element of discussed vision of Good. The reasons for putting emphasis on the global ethical prospect are related first of all to searching of the new social - political paradigm which will cause that the paradigm of sustainable development will be acceptable all over the world (Kopfmüller, 2001).

Passing to the conclusions it should be ascertained that the ethics of sustainable development from the pages of the Brundtland Report is the development of the vision of good which was based on the right of each human being living currently and in the future to implement his/her fair aspirations.

\section{Conclusion}

The contemporary political ideas are usually interpreted in the wide context of social, economic and political life on the basis of affirmation or negation of predominant values and convictions and popularized threads of scientific theories. It also applies to the political idea of sustainable development. That is why in the analyses of the ethics of sustainable development which were carried out in the present article it was not confined to immanent reading out the contents of the Brundtland Report. The task assigned to the analyses could not be finished in the description of their subject because it was to bring about comprehension of the subject of researches. Referring to the primary rules of philosophical heuristics led to conclusions, in the light of which the ethics of sustainable development from the Brundtland Report meets the criteria set by Badiou in front of ethics being capable of having a potential indispensable for initiating the social change. The presented conclusion does not settle decisively an issue of the causative effectiveness of the discussed version of the ethics of sustainable development. It only shows that the discussed ethical standpoint has passed successfully the first test for possible usability in fighting against some forms of Evil.

In order to answer decisively the question if the ethics of sustainable development from the Brundtland Report has real causative power and is efficient in initiating and performing social changes - according to philosophical standpoint of Badiou it has to be put to the consecutive tests. The following research problem which in connection to that should be set concerns the conformity of discussed version of the ethics of sustainable development with formal requirements, which Badiou imposes in front of his own ethical standpoint, so called the ethics of truth.

\section{References}

1. BADIOU A., 2001, Ethics. An Essay on the Understanding of Evil, Verso, London - New York.

2. BRAND K.-W., 1997, Probleme und Potentiale einer Neubestimmung des Projekts der Moderne unter dem Leitbild ,nachhaltige Entwicklung'. Zur Einführung, in: Nachhaltige Entwicklung. Eine Herausforderung an die Soziologie, ed. Brand K.-W., Leske + Budrich Verlag, Opladen, p. 9-32.

3. JONAS H., 1979, Das Prinzip Verantwortung: Versuch einer Ethik für die technologische Zivilisation, Insel-Verlag, Frankfurt am Main.

4. KOPFMÜLLER J. et al., 2001, Nachhaltige Entwicklung integrativ betrachtet. Konstitutive Elemente, Regeln, Indikatoren, Edition Sigma, Berlin.

5. PAPUZIŃSKI A., 2017, Filozofia Raportu Brundtland, in: Theoria $i$ praxis zrównoważonego rozwoju. 30 lat od ogtoszenia Raportu Brundtland, eds. Sadowski R. F., Łepko Z., Towarzystwo Naukowe Franciszka Salezego, Warszawa, p. 127-130.

6. PAWŁOWSKI A., 2008, Rozwój zrównoważony idea, filozofia, praktyka, Komitet Inżynierii Środowiska PAN, Lublin.

7. RAWLS J., 2001, A Theory of Justice. Revised Edition, The Belknap Press of Harvard University Press, Cambridge, Mass.

8. REDCLIFT, M. R., 2009, Sustainable Development (1987-2005) - an Oxymoron Comes of Age, in: Problemy Ekorozwoju / Problems of Sustainable Development, 4(1), p. 33-50.

9. SANDEL M., 2012, What Money Can't Buy: The Moral Limits of Markets. Farrar, Straus and Giroux, New York.

10. TIBALDEO R. F., 2015, The Heuristics of Fear: Can the Ambivalence of Fear Teach Us Anything?, in: Ethics in Progress, 6(1), p. 225-238.

11. UN, 1945, United Nations Charter, Article 1, http://www.un-documents.net/charter.htm\#chapter-1 (20.05.2018).

12. WCED (World Commission on Environment and Development), 1987, Our Common Future, http://www. un-documents.net/ocf-ov.htm (19.07.2018).

13. WALZER M., 1994, Thick and Thin: Moral Argument at Home and Abroad, Notre Dame Press, Notre Dame, Indiana. 